\title{
The western Barents Sea and the Svalbard archipelago 18000 years ago - a finite-difference computer model reconstruction
}

\author{
ELISABETH ISAKSSON \\ Institute for Quaternary Studies, University of Maine, Orono, Maine 04469, U.S.A.*
}

\begin{abstract}
A finite-difference computer model was used to reconstruct a steady-state ice sheet over the western Barents Sea and the Svalbard archipelago at the last glacial maximum $18000 \mathrm{BP}$. Flowlines were reconstructed from the ice margin to the ice dome based on information about glacial geology, bedrock topography, basal thermal regime and the present precipitation pattern. The modelling result suggests a $1700 \mathrm{~m}$ high marine ice dome east of Spitsbergen and a $1350 \mathrm{~m}$ high terrestrial dome over northwest Spitsbergen. Over most of the terrestrial areas, the bed is frozen while in the marine areas the bed is thawed. This is in agreement with both the terrestrial and the marine glacial geology records. The height of the terrestrial dome implies that the ice sheet was thin and left several of the higher mountain peaks as nunataks. Three major ice streams were reconstructed in the most pronounced over-deepened marine channels. This modelling experiment did not allow any major ice streams in the fjords of Spitsbergen during steady-state conditions.
\end{abstract}

\section{INTRODUCTION}

Was there an ice sheet over the Barents Sea during the last glacial maximum? This question has been discussed with great intensity since De Geer (1900) first suggested an extensive glaciation in the Barents Sea area. Several different hypotheses have developed since. The two most extreme hypotheses in each direction are: one that features both extensive marine ice domes and ice shelves in the Barents Sea and surrounding basins at $18000 \mathrm{BP}$ (Hughes and others, 1977; Grosswald, 1980; Andersen, 1981), and another that limits the glaciation to the coasts of the islands in the Svalbard archipelago (Boulton, 1979; Boulton and others, 1982). The supporters of the latter hypothesis base their ideas on the lack of glacial erosion and terminal moraines on the islands in the Barents Sea. That together with ${ }^{14} \mathrm{C}$ and amino-acid dates of shells are interpreted as evidence against any widespread glaciation younger than 40000 year BP. However, strong evidence for an extensive marine glaciation during the late Weichselian are: (1) the Holocene isostatic uplift rate which indicates maximum uplift over the Barents Sea (Schytt and others, 1968; Salvigsen and Nydal, 1981), and (2) a sediment succession, without any hiatuses, of

\footnotetext{
* Present address: Department of Physical Geography, Stockholm University, S-106 91, Stockholm, Sweden.
}

basal till-glaciomarine sediments - Holocene postglacial sediments in large parts of the Barents Sea (Elverhøi and Solheim, 1983).

Glacial modelling including the Barents Sea area have previously been performed by Denton and Hughes (1981a), and more recently by Lindstrom (1990). Neither of these modelling experiments considered the Barents Sea area in particular. In this modelling exercise, I have reconstructed one possible configuration of a steady-state ice sheet over the Svalbard archipelago and the western Barents Sea using a one-dimensional, finitedifference computer model developed at the University of Maine by T. Hughes and J. Fastook (Hughes and others, 1981; Fastook, 1984; Hughes, 1985; Fastook and Hughes, 1988). The model reconstructs the ice-surface elevation as output based on information about the glacial geology, bed topography, basal conditions, mass balance, flowband width, ice-stream length and flow-law constants.

\section{THE FINITE DIFFERENCE FLOW-BAND MODEL}

This finite-difference computer model was developed for the CLIMAP reconstruction of three-dimensional steadystate ice sheets $18000 \mathrm{BP}$ (Denton and Hughes, 1981b). Later modification of the model made it possible to change the input parameters, such as accumulation and ablation rates and flow-band widths (drainage area), along each flowline (Hughes, 1985). One advantage with this modification is that each flow band can be fitted in to 
the topography. This is particularly important when including ice streams in the ice-sheet complex.

The model reconstructs surface profiles along given flowlines from the ice margin to the ice divide. The basis for reconstructing former ice sheets with this finitedifference flow-band model, is the fundamental formula:

$$
\tau_{0}=\rho_{\mathrm{I}} g h_{\mathrm{I}} \alpha
$$

where $\tau_{0}$ is the basal shear stress, $h_{\mathrm{I}}$ the ice thickness, $\alpha$ the ice-surface slope, $\rho_{\mathrm{I}}$ the ice density and $g$ the gravity acceleration (British Glaciological Society, 1949). Each flowline lies within a flow band that can have variable width and is divided into steps of equal length. For each $\Delta x$ step, the topography, the basal thermal regime, the flow-band width and the mass balance have to be specified. The glacial geology is used to find the initiating first step in the calculation. From this information, values of $\tau_{0}$ are calculated for each step. Ice elevations for each step along the flowline $h_{i+1}$ can be computed using the following finite-difference recursion formula:

$$
h_{i+1}=h_{i}+\left[\frac{\tau_{0}}{\left(h-h_{\mathrm{R}}\right)}\right]_{i} \frac{\Delta x}{\rho_{\mathrm{I}} g}
$$

where $h$ is the surface elevation of the ice at the initial step and $h_{\mathrm{R}}$ is the bedrock elevation. Each flow band is divided into $i$ steps of the same step length $\Delta x$. This expression neglects longitudinal stress gradients and transverse stresses, a valid assumption for distances greater than four times the ice thickness (Budd, 1971). In this experiment 20 and $10 \mathrm{~km}$ finite-difference steps are used. Isostatic depression is modelled by an arbitrary smooth function that ranges from zero depression right at the ice margin to full depression at the ice divide, as determined from the density of the ice mass and the bedrock mantle. For greater accuracy, flow- and slidinglaw constants are included in the model The basal shearstress variations along the surface flowlines are calculated using the continuity equation for a flat horizontal bed (Fastook, 1984):

$$
\int \dot{a} w \mathrm{~d} x-\int \frac{\delta h}{\delta t} w \mathrm{~d} x+\int \mathrm{d}(u w h)=0
$$

where $\dot{a}$ is the accumulation/ablation rate, $w$ is the flowband width, $(\delta h / \delta t)$ is the change of $h$ in time $t$ when the ice sheet is not in equilibrium, $u$ is the mean horizontal ice velocity in the flow band, measured a distance $x$ from the ice margin.

For a frozen (dry) bed $\tau_{0}=\tau_{\mathrm{D}}$ in the flow law and for a thawed (wet) bed $\tau_{0}=\tau_{\mathrm{W}}$ in the sliding law. Finally, the basal shear-stress distribution for a bed with a combination of frozen and thawed bed is calculated (Fastook, 1984):

$$
\tau_{0}=F \tau_{\mathrm{D}}+(1+F) \tau_{\mathrm{W}}
$$

where $\tau_{\mathrm{D}}$ and $\tau_{\mathrm{W}}$ are the basal shear stress for frozen (dry) and thawed (wet) bed, respectively, and $F$ is the fraction of the bed that is thawed.

Reconstructing a former ice sheet with this finitedifference model requires identifications of the ice margins, major ice domes, surface flowlines, basal conditions and the equilibrium line.

\section{THE BARENTS SEA ICE SHEET - BOUNDARY CONDITIONS}

\section{Ice margins}

How big was the late Weichselian ice sheet in the Barents Sea area? The most critical part of this experiment is to define the ice-sheet boundaries 18000 year BP. The ice margins can either be terrestrial or marine. Both are included in this experiment.

Terminal moraines and other glacial geological evidence are rare on the terrestrial parts of Svalbard. The marine records provide more information about the extension of former ice sheets. A number of submarine ridges interpreted as moraine ridges are found in the mouths of submarine valleys around Spitsbergenbanken (Elverhøi, 1984). Because these features are observed at the same water depth, $250-300 \mathrm{~m}$, it seems reasonable to believe that they define the grounded limit of the ice sheet in the area (Elverhøi and Solheim, 1983). However, it is difficult to date these ridges. Dating is particularly difficult in polar areas because of the lack of reliable stratigraphical points and organic material. Furthermore, available dates are hard to interpret because various glacial reworking processes are common (Blake, 1989).

A decision on former ice margins of the Barents Sea ice complex (Fig. 1) was made on the basis of field evidence from available literature (Hoppe and others, 1969; Damuth, 1978; Elverhøi and Solheim, 1983; Elverhøi, 1984), and in co-operation with Professor W. Karlén, University of Stockholm. The $250-300 \mathrm{~m}$ contour was used as the grounding line for the marine margins. The margin at northwest Spitsbergen is terrestrial in this experiment. The position of the ice margin here depends on the fact that the flowlines in a steady-state ice sheet have to be of nearly the same length (Hughes, 1985).

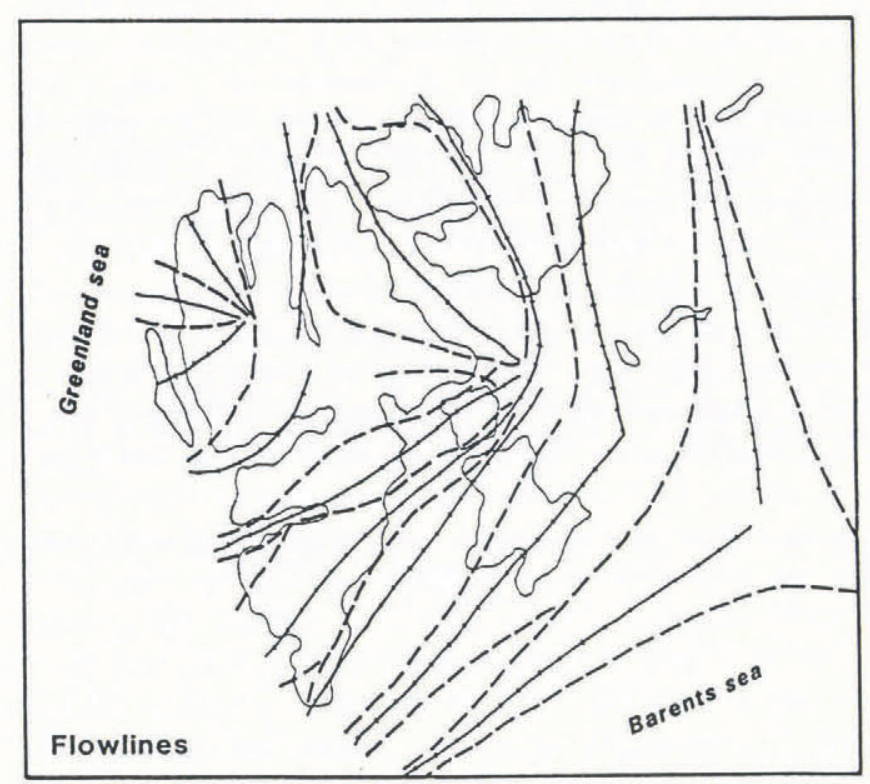

Fig. 1. Map of Svalbard and the adjacent Barents Sea with flowlines used in this reconstruction. Flowlines are shown as heavy solid lines, segmented for each finitedifference step. Boundaries for flow bands are shown by heavy dashed lines. 


\section{The ice divide}

Along an ice divide an alternating sequence of domes and saddles exists. From geological evidence (De Geer, 1900; Blake, 1961; Schytt and others, 1968; Hoppe and others, 1969; Strömberg, 1972) and sedimentological evidence (Elverhøi and Solheim, 1983; Elverhøi, 1984; Vorren and Kristoffersen, 1986), it is suggested that a grounded marine ice sheet occupied the Barents Sea. The highest rates of postglacial uplift in the Svalbard region have been recorded from the area southeast of Hinlopenstredet (Schytt and others, 1968; Boulton, 1979) and east of Kong Karls land (Salvigsen and Nydal, 1981). Based on these indications, the major ice dome, in the area for this reconstruction, is situated south of Hinlopenstredet. A saddle separates this dome from a major ice dome in the central Barents Sea (Andersen, 1981) or farther east in the Kara Sea (Grosval'd, 1988). During the modelling it became obvious that for the selected ice-sheet configuration it was necessary to have a separate dome over the highlands of northern Spitsbergen.

\section{Flowlines}

The flowlines were reconstructed from the topographical maps Spitsbergen, Söre del (Blad 1), Edgeøya (Blad 2), Vestspitsbergen, Nordre del (Blad 3), Nordaustlandet (Blad 4) and the bathymetric map, Svalbard 2751, using the knowledge that ice flow has a tendency to follow lower parts in the bed topography. Altogether, 14 flowlines were reconstructed (Fig. 1), beginning with $20 \mathrm{~km}$ steps. A shorter step length was necessary for some of the flowlines over northwest Spitsbergen in order to satisfy the minimum number of steps the model requires. For these flowlines (a total of five), $10 \mathrm{~km}$ steps were used.

Previous experiments show that this model is more sensitive to the flow-band length than to the basal thermal regime and, to be able to use the model at its "full effect", the flowlines should be constructed so that they are more or less equal in length.

\section{Basal conditions}

Marine ice domes can form in two different ways (Hughes and others, 1981) which lead to different interpretations of the basal conditions. One way is by the spreading of terrestrial ice on to isostatically depressed continental shelves. For this to occur, a shallow-water basin is required, and the basal condition of the developing marine dome is likely to be thawed, unless it was not already frozen (permafrost). The other mechanism involves thickening of pack ice. In this case, there is initially a thawed bed, because the remanent sea water became increasingly saline. Therefore, the basal ice could maintain a lower temperature and the bed became frozen. On the other hand, if water currents swept away this high-saline water, the sea ice may have grounded on a thawed bed.

I chose a thawed bed beyond the present-day shoreline for this reconstruction of the ice sheet over the Svalbard area, because the submarine troughs seem to have been modified by ice streams (that is, troughs were foredeepened).
Terrestrial ice forms by lowering of the snow line in higher-elevation areas. These areas presumably had permafrost conditions before they were glaciated. Therefore, terrestrial ice domes are more likely to have frozen beds.

The first-order glacial erosion-deposition pattern of the landscape gives valuable information about the impact of former steady-state conditions (Hughes, 1981). This must not be confused with the overprint of lateglacial conditions, as that was a phase that lasted for a short time compared to the steady-state conditions that had been approached for glaciation after glaciation during the Pleistocene (Hughes and Fastook, 1988).

Different basal conditions produce different landscapes of glacial erosion. Sugden $(1974,1977,1978)$ has discussed this fact in several papers and applied these theories to the present Greenland ice sheet as well as to the former Laurentide ice sheet. Deformation in ice that is below the pressure-melting point is concentrated within the lower layers of the ice mass; in addition, ice at its pressure-melting point has sliding movement between ice and bedrock. Basal sliding leads to glacial erosion and that develops a landscape of areal scouring (Sugden and John, 1976). Because the reconstruction of the ice sheet over the Svalbard archipelago includes a limited area, well-developed first-order landscape zonations do not exist.

The ice pressure-melting temperature rises with increasing ice thickness. Therefore, the central parts of an ice sheet are more likely to have a thawed bed than the peripheral thinner ice. Furthermore, a melting bed is likely to occur with low surface accumulation and converging flow, whereas a freezing or frozen bed is more likely for diverging flow and high surface accumulation. As the glacier bed becomes more "lubricated" with meltwater, the ice sheet will increase

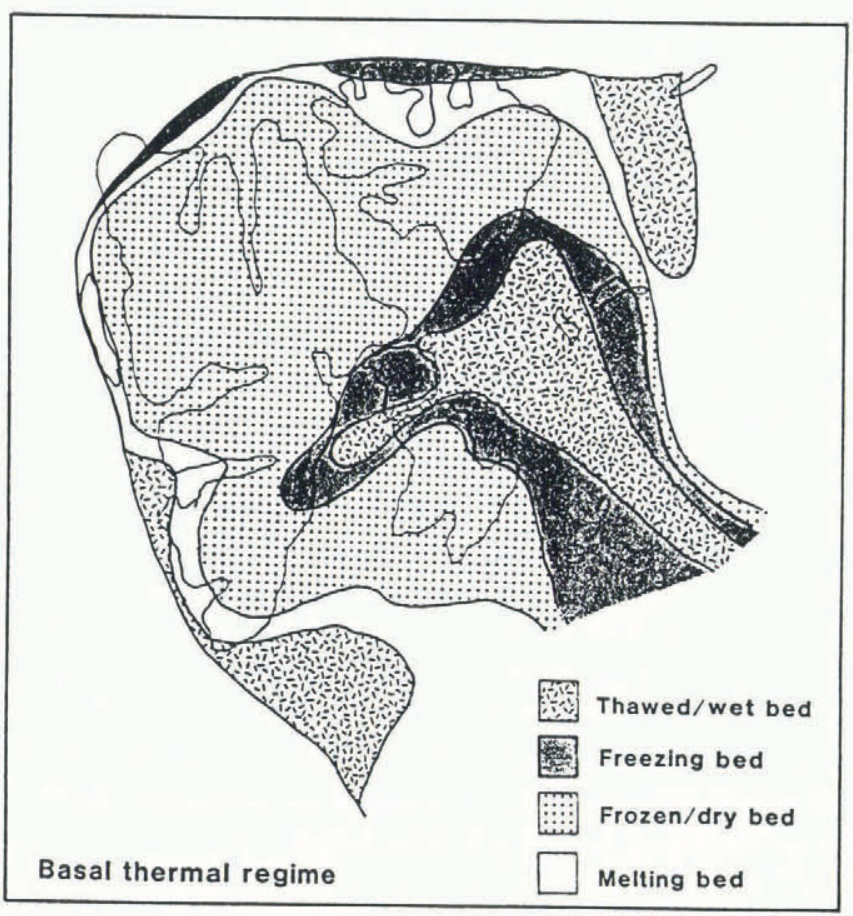

Fig. 2. The Svalbard archipelago with the basal thermal regimes used in this model exercise. 


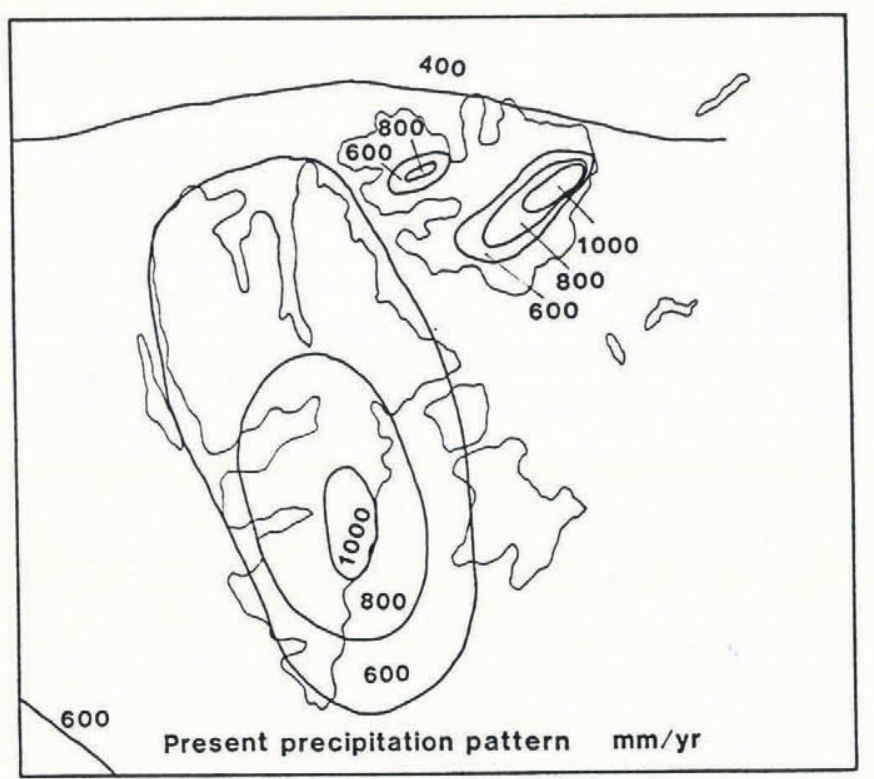

Fig. 3. Present precipitation pattern over Svalbard (after Schytt, 1964; Treshnikov, 1985).

its area and decrease its thickness to maintain dynamic equilibrium.

Because none of the high-elevation terrestrial parts of the islands in the Svalbard area show any evidence of an over-riding ice sheet in the form of extensive areal scouring, striations or till cover, the ice over these areas was supposed to have been frozen during the main glacial phase. To be able to fit that with the thawed dome requires a freezing zone in between. This zone also includes some of the terrestrial part, such as Barentsøya. The basal thermal regime chosen for this experiment is shown in Figure 2.

\section{Mass balance}

There is no particular reason to assume that during the last glacial maximum the atmospheric circulation was different from now. Work in the North Atlantic indicates that a large part of the sub-polar area of the Norwegian Sea acted as a moisture supply even during the most extensive glaciation (McIntyre and tohers, 1976; Ruddiman and McIntyre, 1981). In this experiment the present precipitation rate (Fig. 3) from various published sources was used (Schytt, 1964; Treshnikov, 1985). This precipitation pattern was modified to fit the configuration of the ice sheet on the basis of present accumulation patterns on ice sheets and distance to moisture sources (Fig. 4). The $18000 \mathrm{BP}$ mass balance in the area is believed to have been positive, as the heat transport from the North Atlantic Current was non-existent during glacial times (Ruddiman and McIntyre, 1973; Kellogg, 1975). This caused lower sea-surface temperatures and lowered the snow line close to sea level in the North Atlantic area (Hughes and others, 1977). The ablation for the reconstructed ice sheet is supposed to have occurred by calving, just as in Antarctica today.

\section{Present ice sheets}

A large part of the present ice masses of Svalbard are

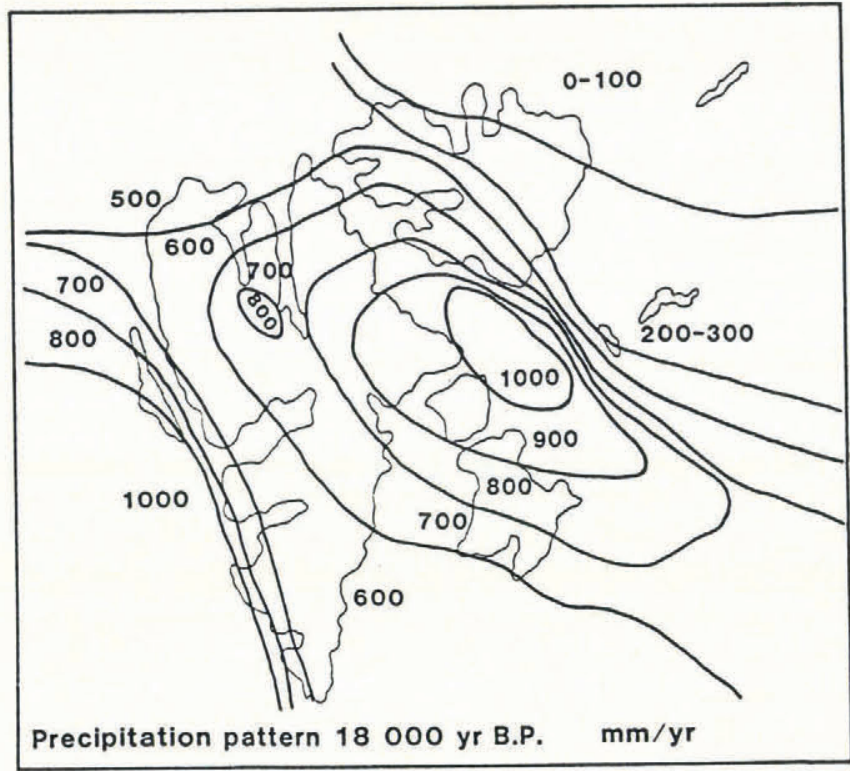

Fig. 4. The modified precipitation pattern used for this reconstruction.

mainly located on east-facing slopes, which is towards the principal source of winter cyclones. The elevations of the various present glaciers and ice caps on the Svalbard islands were taken as bed-topography elevations in the model. Presumably, their thicknesses are not great enough to affect the output ice elevation (personal communication from J. Fastook). On the other hand, the ice caps over Nordaustlandet are thick enough to be corrected for in the model. Seismic refraction and reflection measurements from Ekman (1971) and Dowdeswell and others (1984) were used for this purpose.

\section{Ice streams}

In present-day ice sheets a considerable amount of the ice volume is drained by ice streams. Therefore, ice streams are also believed to have been an important part of former ice complexes.

Ice streams form near the margins of ice sheets where the ice is thin enough to be channelled by bed topography. Ice streams can be either terrestrial or marine but they seem to be more common along marine margins. A terrestrial ice stream forms an ice lobe at the margin and a marine ice stream forms an ice tongue. Furthermore, the surface flowlines for large ice streams often originate at saddles on the ice divide where ice converges from two interior ice domes. Bed topography both in the marine and the terrestrial parts of the area is rugged with deep fjords and submarine over-deepened troughs where ice is likely to have been channelled and where ice streams formed. In this exercise, marine ice streams are reconstructed only in fore-deepened channels.

\section{RESULTS AND DISCUSSION}

The ice-sheet configuration for the boundary conditions discussed is shown in Figure 5. With the present precipitation pattern and the chosen basal thermal regime, a steady-state ice sheet with a marine dome of 


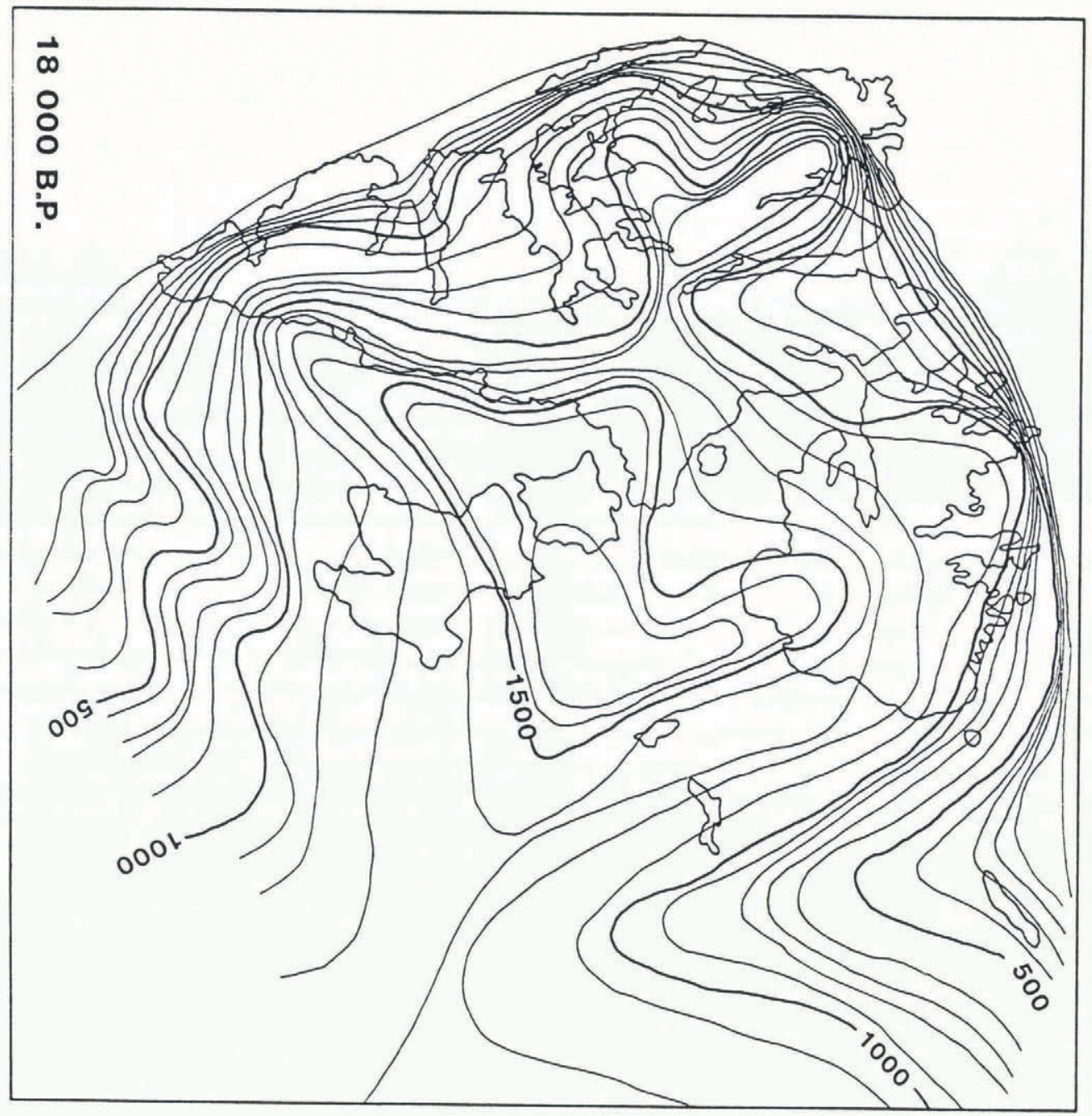

Fig. 5. The extension and the ice elevation for the reconstructed steady-state ice sheet over Svalbard and the adjacent Barents Sea 18000 years ago. The contour interval is $100 \mathrm{~m}$.

$1700 \mathrm{~m}$ elevation can be reconstructed. A smaller terrestrial dome-ice ridge, $1350 \mathrm{~m}$ high, is situated over the high-elevation part of northwest Spitsbergen. The ice sheet over this area is thin and several of the higher mountain peaks are nunataks. The question of an ice-free area in this westernmost part of Spitsbergen (Salvigsen and Nydal, 1981; Forman, 1989; Miller and others, 1989) does not affect elevation of the ice sheet over the rest of Svalbard. According to Hughes and others (1977), channelling of sheet flow into stream flow and acceleration of ice movement can result in unglaciated areas between ice streams, instead of leaving thin ice further inland. This part is therefore included in this reconstruction.

Three marine ice streams have been included in this reconstruction, two in the marine over-deepened channels southeast of Spitsbergen and another in the channel east of Nordaustlandet. With this reconstruction, any major ice streams were not possible during steady-state conditions in the fjords along the west coast of Spitsbergen. This is because flowlines with ice streams have a lower elevation than other flowlines, and therefore they do not match up to the ice-dome elevation.

Can the basal thermal-regime conditions used in this experiment explain the sediment distribution in this part of the Barents Sea? The presence of exposed bedrock in the northern parts of the Barents Sea (Solheim and Kristoffersen, 1984) implies extensive glacial erosion. This corresponds to the conditions of a thawed bed under the dome, allowing basal sliding and erosion. Because ice streams have a thawed bed, erosion can occur there as well. This is often replaced by deposition in the peripheral parts of the ice stream if it terminates in deep water and is uncoupled from the bed, producing thick sediment fans confined to the continental shelf edge where the marine over-deepened troughs terminate.

Could the marine ice sheet in this reconstruction exist without an ice shelf? Whether an ice shelf is necessary for buttressing this particular ice sheet is purely speculative. If no ice shelf existed, the ice streams terminated as floating ice tongues and the grounding line would be very sensitive to any changes in sea level (Hughes and others, 1977; Fastook, 1984). Without a doubt, an ice shelf would give the Barents Sea ice sheet more stability but it is possible for this ice sheet to be stable because of the lower sea level during the glacial maximum. However, discussions of an ice shelf in the Arctic Ocean are beyond the scope of this paper.

It is interesting to speculate about disintegration of the reconstructed ice sheet. During deglaciation, when the ice sheet was thinner, ice streams most likely occupied some of the fore-deepened submarine valleys and fjords in the 
area. Hinlopenstredet is such a channel. As this is a deep marine channel, it was very sensitive to any rise in sea level which could result in marine down-draw (Hughes and others, 1977). This could have happened in an early stage of the deglaciation when the depression of the Barents Sea floor had reached a critical point (Denton and Hughes, 1981a). Rapid disintegration of the marinebased Barents Sea ice sheet could be responsible for the pronounced light-oxygen isotope event in Fram Strait at $15000 \mathrm{BP}$ (Jones and Keigwin, 1988).

\section{CONGLUSIONS}

This modelling exercise has not solved the mystery of the existence of a Barents Sea ice sheet, but it has given one possible configuration of a steady-state ice sheet that could have existed in the Svalbard archipelago 18000 year BP and was a part of a Barents Sea ice sheet. Neither does this exercise provide answers to the controversial issues concerning the extension and the timing of the Barents Sea ice sheet. But it does show the possibility of maintaining a steady-state ice sheet in this area, using realistic boundary conditions.

\section{ACKNOWLEGEMENTS}

I am grateful to T.J. Hughes who initiated this work during my stay at the Institute for Quaternary Studies, University of Maine. J.L. Fastook introduced the computer model to me and patiently answered questions. W. Karlén gave valuable suggestions about the extension of the ice sheet. Critical comments from T.J. Hughes, S. Jonsson, J. Kohler and an anonymous reviewer improved this paper. Financial support was provided by the Swedish National Council, Institute for Quaternary Studies, American Swedish Foundation and the Liljevalchs Foundation.

\section{REFERENCES}

Andersen, B. G. 1981. Late Weichselian ice sheets in Eurasia and Greenland. In Denton, G. H. and T.J. Hughes, eds. The last great ice sheets. New York, John Wiley and Sons, 1-65.

Blake, W., Jr. 1961. Radiocarbon dating of raised beaches in Nordaustlandet, Spitsbergen. In Raasch, G. O., ed. Geology of the Arctic. 1. Toronto, University of Toronto Press, 133-145.

Blake, W., Jr. 1989. Radiocarbon dating by accelerator mass spectrometry: a contribution to the chronology of Holocene events in Nordaustlandet, Svalbard. Geogr. Ann., 71A(1-2), 59-74.

Boulton, G.S. 1979. Glacial history of the Spitsbergen archipelago and the problem of a Barents Shelf ice sheet. Boreas, 8(1), 31-57.

Boulton, G.S. and 13 others. 1982. A glacio-isostatic facies model and amino acid stratigraphy for late Quaternary events in Spitsbergen and the Arctic. Nature, 298(5813), 437-441.

British Glaciological Society. 1949. Joint meeting of the
British Glaciological Society, the British Rheologists' Club and the Institute of Metals. F. Glaciol., 1(5), 231240.

Budd, W.F. 1971. Stress variations with ice flow over undulations. 7. Glaciol., 10(59), 177-195.

Damuth, J.E. 1978. Echo character of the NorwegianGreenland Sea: relationship to Quaternary sedimentation. Mar. Geol., 28, 1-36.

De Geer, G. 1900. Om östra Spetsbergens glaciation under istiden. Geol. Fören. Stockholm Förh., 22(5), 427436.

Denton, G. H. and T.J. Hughes. 1981a. The Arctic ice sheet: an outrageous hypothesis. In Denton, G. H. and T.J. Hughes, eds. The last great ice sheets. New York, John Wiley and Sons, 437-467.

Denton, G. H. and T.J. Hughes, eds. 1981b. The last great ice sheets. New York, John Wiley and Sons.

Dowdeswell, J.A., D.J. Drewry, O. Liestøl and O. Orheim. 1984. Airborne radio echo sounding of subpolar glaciers in Spitsbergen. Nor. Polarinst. Skr. 182.

Ekman, S.R. 1971. Seismic investigations on the Nordaustlandet ice caps. Geogr. Ann., 53(1), 1-13.

Elverhøi, A. 1984. Glacigenic and associated marine sediments in the Weddell Sea, fjords of Spitsbergen and the Barents Sea: a review. Mar. Geol., 57(1-4), 53-88.

Elverhøi, A. and A. Solheim. 1983. The Barents Sea ice sheet - a sedimentological discussion. Polar Res., 1(1), n.s., 23-42.

Fastook, J.L. 1984. West Antarctica, the sea-level controlled marine instability: past and future. In Hansen, J.E. and T. Takahashi, eds. Climate processes and climate sensitivity. Washington, DC, American Geophysical Union, 275-287. (Geophysical Monograph 29.)

Fastook, J.L. and T.J. Hughes. 1988. A geomorphic method for reconstructing paleo ice sheets. Part 2. Glaciology. In Kite, J.S., T. V. Lowell and W.B. Thompson, eds. Contributions to the Quaternary geology of northern Maine and adjacent Canada. Maine Geol. Surv. Bull. 37, 19-34.

Forman, S. 1989. Late Weichselian glaciation and deglaciation of Forlandsundet area, western Spitsbergen, Svalbard. Boreas, 18(1), 51-60.

Grosswald, M.G. 1980. Late Weichselian ice sheet of northern Eurasia. Quat. Res., 13(1), 1-32.

Grosval'd, M.G. 1988. Oledeneniye antarkticheskogo tipa v Severnom polusharii (na puti k Novoy global'noy lednikovoy teorii) [Antarctic-style ice sheet in the Northern Hemisphere (toward a new global glacial theory)]. Materialy Glyatsiologicheskikh Issledovaniy 63, 325.

Hoppe, G., V. Schytt, A. Häggblom and H. Österholm. 1969. Studies of the glacial history of Hopen (Hopen island), Svalbard. Geogr. Ann., 51A(4), 185-192.

Hughes, T.J. 1981. Numerical reconstruction of paleo-ice sheets. In Denton, G. H. and T. J. Hughes, eds. The last great ice sheets. New York, John Wiley and Sons, 221261.

Hughes, T.J. 1985. The great Cenozoic ice sheet. Palaeogeogr. Palaeoclimatol. Palaeoecol., 50(1), 9-43.

Hughes, T.J. and J.L. Fastook. 1988. A geomorphic method for reconstructing paleo ice sheets. Part 1 . Glacial geology. In Kite, J. S., T. V. Lowell and W. B. 
Thompson, eds. Contributions to the Quaternary geology of northern Maine and adjacent Canada. Maine Geol. Surv. Bull. 37, 3-17.

Hughes, T.J., G. H. Denton and M. G. Grosswald. 1977. Was there a late-Würm Arctic ice sheet? Nature, 266(5603), 596-602.

Hughes, T.J., G.H. Denton, B.G. Andersen, D. H. Schilling, J. L. Fastook and C.S. Lingle. 1981. The last great ice sheets: a global view. In Denton, G. H. and T. J. Hughes, eds. The last great ice sheets. New York, John Wiley and Sons, 263-317.

Jones, G.A. and L.D. Keigwin. 1988. Evidence from Fram Strait $\left(78^{\circ} \mathrm{N}\right)$ for early deglaciation. Nature, 336(6194), 56-59.

Kellogg, T. B. 1975. Late Quaternary climatic changes in the Norwegian and Greenland Seas. In Weller, G. and S. A. Bowling, eds. Climate of the Arctic. Fairbanks, AK, University of Alaska, 3-36.

Lindstrom, D. R. 1990. The Eurasian ice sheet formation and collapse resulting from natural atmospheric $\mathrm{CO}_{2}$ concentration variations. Paleoceanography, 5(2), 207227.

McIntyre, A. and 7 others. 1976. Glacial North Atlantic 18,000 years ago: a CLIMAP reconstruction. Geol. Soc. Am. Bull., 145, 43-76.

Miller, G.H., H.-P. Sejrup, S.J. Lehman and S.L. Forman. 1989. Glacial history and marine environmental change during the last interglacial-glacial cycle, western Spitsbergen, Svalbard. Boreas, 18(3), 273-296.

Ruddiman, W.F. and A. McIntyre. 1973. Timetransgressive deglacial retreat of polar waters from the North Atlantic. Quat. Res., 3(1), 117-130.

Ruddiman, W. F. and A. McIntyre. 1981. The North Atlantic Ocean during the last deglaciation. Palaeogeogr. Palaeoclimatol. Palaeoecol., 35, 145-214.

Salvigsen, O. and R. Nydal. 1981. The Weichselian glaciation in Svalbard before 15,000 B.P. Boreas, 10(4),
433-446.

Schytt, V. 1964. Scientific results of the Swedish Glaciological Expedition to Nordaustlandet, Spitsbergen, 1957 and 1958. Geogr. Ann., 46(3), 243-281.

Schytt, V., G. Hoppe, W. Blake, Jr and M. G. Grosswald. 1968. The extent of the Würm glaciation in the European Arctic. International Association of Scientific Hydrology Publication 79 (General Assembly of Bern 1967 Snow and Ice), 207-216.

Solheim, A. and Y. Kristoffersen. 1984. Sediments above the upper regional unconformity: thickness, seismic stratigraphy and outline of the glacial history. Nor. Polarinst. Skr. 179 B.

Strömberg, B. 1972. Glacial striae in the southern Hinlopenstretet and Kong Karls Land, Svalbard. Geogr. Ann., 54A(2), 53-65.

Sugden, D. E. 1974. Landscapes of glacial erosion in Greenland and their relationship to ice, topographic and bedrock conditions. London, Institute of British Geographers, 177-195. (Special Publication 7.)

Sugden, D. E. 1977. Reconstruction of the morphology, dynamics, and thermal characteristics of the Laurentide ice sheet at its maximum. Arct. Alp. Res., 9(1), 2147.

Sugden, D. E. 1978. Glacial erosion by the Laurentide ice sheet. F. Glaciol., 20(83), 367-391.

Sugden, D. E. and B. S. John. 1976. Glaciers and landscape; a geomorphological approach. London, Edward Arnold.

Treshnikov, A. F., ed. 1985. Atlas Arktiki [Atlas of the Arctic]. Moscow, Glavnoye Upravleniye Geodezi i Kartografii pri Sovete Ministrov SSSR.

Vorren, T. O. and Y. Kristoffersen. 1986. Late Quaternary glaciation in the south-western Barents Sea. Boreas, 15(1), 51-59.

The accuracy of references in the text and in this list is the responsibility of the author, to whom queries should be addressed. 